\title{
FOSSIL INSECTS FROM NEW MEXICO ${ }^{1}$
}

\author{
By F. M. Carpenter \\ Biological Laboratories, Harvard University
}

Several years ago Dr. Charles B. Read, of the U. S. Geological Survey, kindly sent me a fossil insect which he had collected in the Sandia Formation (Pennsylvanian age) in New Mexico. Although recognizing the specimen as a member of the extinct order Palaeodictyoptera, I deferred publication on it with the hope that additional insects might subsequently be found in the same deposit. So far none has been, but about a year ago Dr. Sergius Mamay, also of the U. S. Geological Survey, sent me five insects which he had found at an exposure of the Madera Formation in New Mexico. Since these are also of Pennsylvanian age, I decided to publish this account of both the Sandia and the Madera specimens. As on many previous occasions, I am deeply indebted to Dr. Read and to Dr. Mamay for the opportunity of studying these fossils.

The Sandia Formation is considered to be of Lower Pennsylvanian age, probably equivalent to the Pottsville (see Keroher, I966; Bates and others, 1947; Read and Wood, 1947). So far as I am aware the specimen collected by Dr. Read is the only insect which has been found in the Sandia Formation. This fossil, however, is of unusual interest, since it belongs to the palaeodictyopterous family Eugereonidae, which is otherwise known only from the Upper Carboniferous of France and Portugal, and the Permian of Germany.

The Madera Formation is also referable to the Upper Pennsylvanian period but is somewhat younger than the Sandia and may possibly belong to the uppermost Pennsylvanian (Mamay, personal communication; Read and others, 1944; Bates and others, I947; Read and Wood, 1947). The collection made by Dr. Mamay from an exposure of this formation is of exceptional interest. All insects are very well preserved and four of the five specimens have body structures present. This is an unusual occurrence and it takes on even greater significance in view of the systematic positions of the fossils concerned. One of the species seems to be a member of the palaeodictyopterous family Lycocercidae, which has previously been found only in the Upper Carboniferous of France and Germany; another is a member of the extinct order Caloneurodea, which has

\footnotetext{
${ }^{1}$ This research has been supported in part by NSF Grant no. GB 27333 (F. M. Carpenter, Harvard University, Principal Investigator).
} 


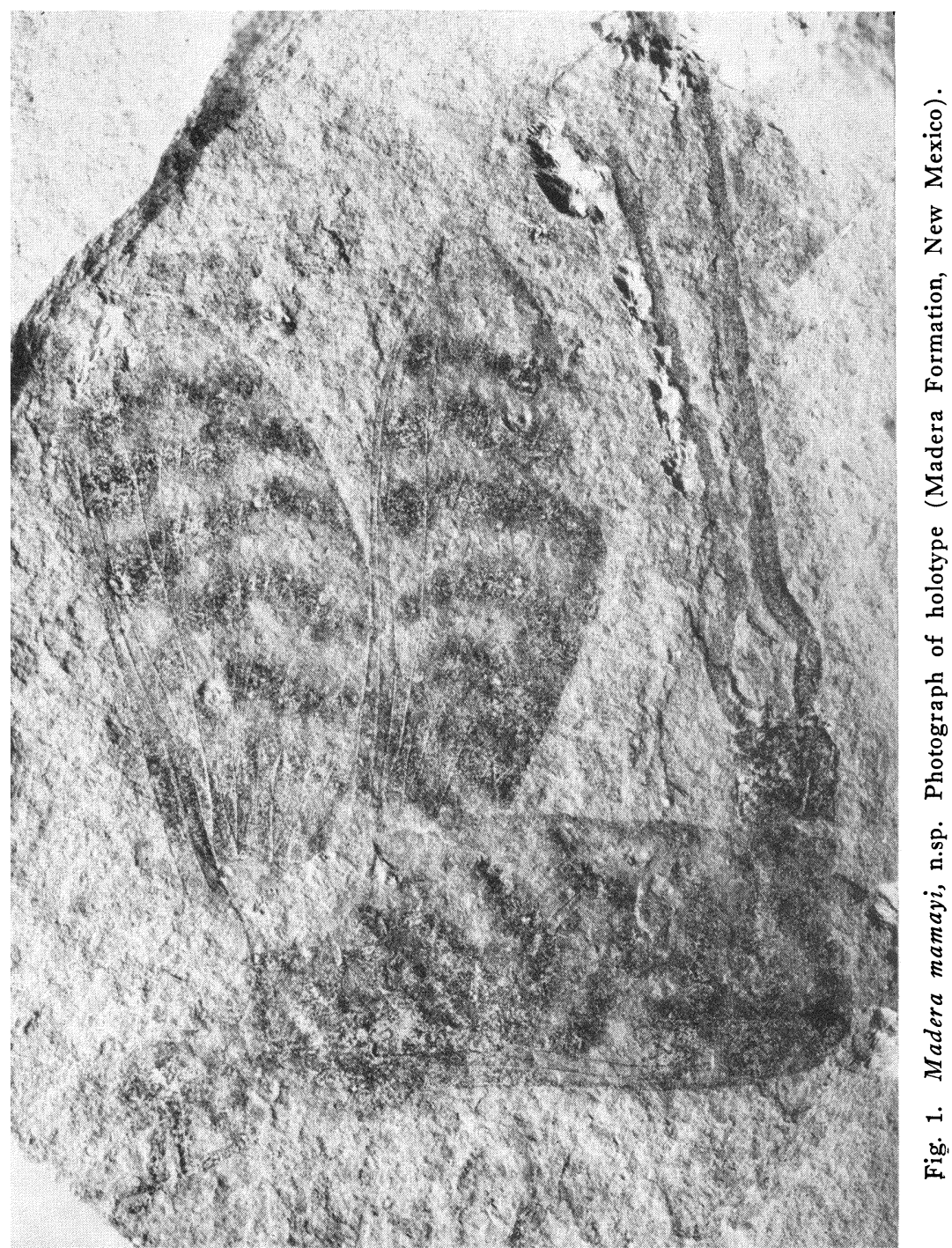


only one previous record from Pennsylvanian deposits of North America, although it is well represented in Upper Carboniferous beds of Europe. The third specimen belongs to the order Thysanura, which has not previously been reported from North American deposits older than the Tertiary; since this specimen is very incompletely preserved, a formal description of it is not being presented at this time. The two remaining specimens are cockroaches, one consisting of a fore wing (tegmen) and the other of a whole insect except for the tegmina; the latter specimen is discussed briefly below but neither of these blattarians is being formally described here.

\section{Order Palaeodictyoptera}

\section{Family Lycocercidae}

As characterized by Kukalová (1969), the members of this family have $\mathrm{MA}$ and $\mathrm{CuA}$ unbranched, $\mathrm{MP}$ and $\mathrm{CuP}$ branched, and the cross veins fine, numerous and more or less irregular. The family has not previously been reported from any deposit in North America, although $\mathrm{I}$ have in my possession a representative of the family from the vicinity of Mazon Creek (Francis Creek Shales) in northern Illinois (Pennsylvanian Period).

\section{Genus Madera, new genus ${ }^{2}$}

This genus contains species which are much smaller than those in Lycocercus; the fore and hind wings are relatively broad, compared to those of Lycocercus; MA in both pairs of wings arises at about the level of the origin of $\mathrm{Rs}$, and $\mathrm{CuP}$ consists of two long branches, without marginal forks.

Type species: Madera mamayi, new species.

I have placed this genus in the Lycocercidae mainly on the basis of the unbranched MA and $\mathrm{CuA}$, a feature which seems to be consistent and reliable, as pointed out by Kukalová ( 1969). This single condition of $\mathrm{MA}$ and $\mathrm{CuA}$ actually occurs in several families but all of them except Lycocercidae possess peculiar characteristics absent in Madera. My first thought on examining this new species of Madera was that it was related to the genus Eubleptus, which contains species of about the same size. However, with the presence in Eubleptus of a branched MA and a forked CuP, the Eubleptidae are clearly members of that ccmplex of Palaeodictyoptera in which these two veins are branched. In shape, the wings of Madera

\footnotetext{
${ }^{2}$ The name of the genus is derived from that of the village of La Madera, New Mexico, and is considered feminine.
} 
recall those of some of the Spilapteridae but they have no other characteristics of that family. A separate family may eventually be needed for Madera; for the present it seems advisable to place it in the family Lycocercidae rather than to add another family to the long list of those in the Palaeodictyoptera which are monospecific and based upon unique specimens.

\section{Madera mamayi, n. sp.}

Figures $I$ and 2

Fore wing: length, as preserved, $15 \mathrm{~mm}$ (estimated wing length I $5.5 \mathrm{~mm}$ ) ; width of fore wing, $5.5 \mathrm{~mm}$. Hind wing: length, $14 \mathrm{~mm}$; width, as preserved, $5 \mathrm{~mm}$. Fore and hind wings with six conspicuous transverse bands of dark pigmentation, as shown in the photograph, Figure I. The venational details are included in Figure 2; the number of branches on Rs and MP differs slightly in the fore and hind wing but this is only consistent with what has previously been noted in other Palaeodictyoptera.

The prothorax and fragments of some of the legs are preserved in this specimen but not well enough to allow me to make out details. The terminal portion of the abdomen is also preserved; this clearly terminates in a pair of conspicuous cerci, which are bow-shaped

A
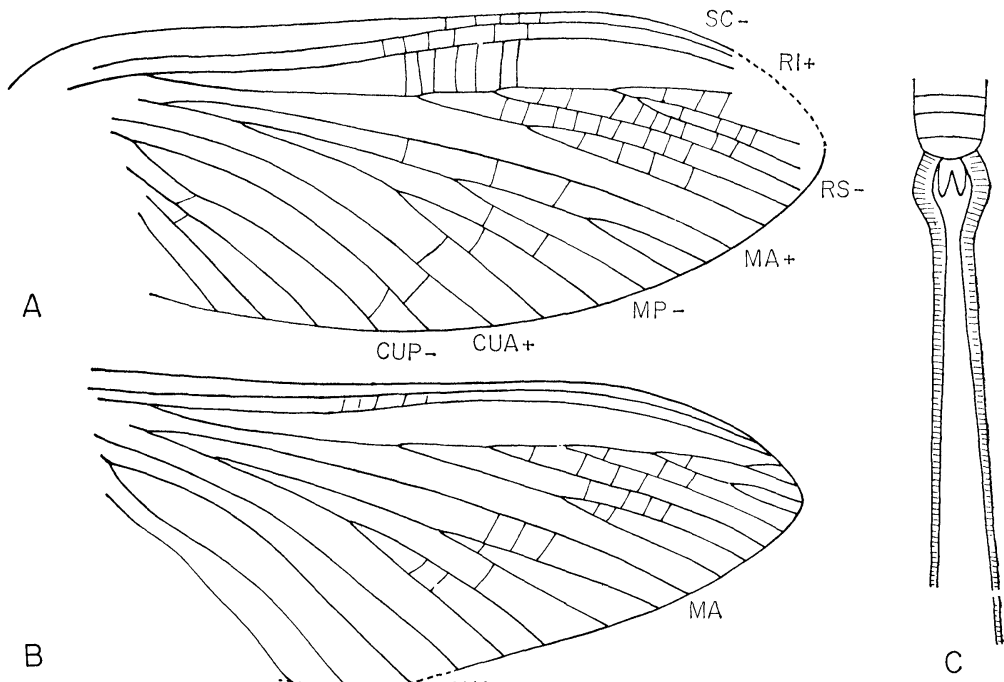

B

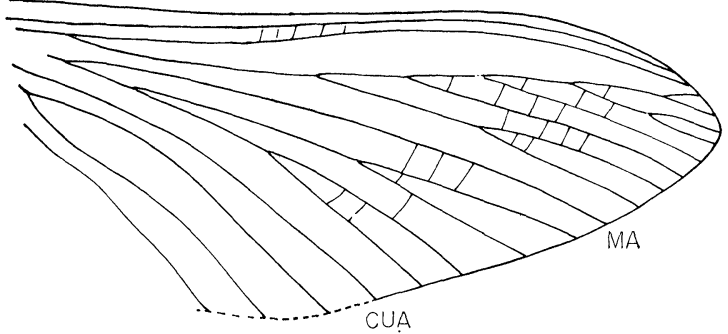

Fig. 2. Madera mamayi, n.sp. Drawing of fore wing (A), hind wing (B) and terminal portion of abdomen and cerci (C). 
shortly beyond their origin (Figure 3 ). The cerci as preserved are I $7 \mathrm{~mm}$ long but they are clearly broken off at this point and were therefore longer in the original insect. Between the cerci there is a pair of short, stout processes, faintly but clearly preserved (length I.5 $\mathrm{mm}$ ). The species is named for Dr. Sergius Mamay, who has sent me many fine specimens of Paleozoic insects during the past decade.

Holotype: No. I70365 U. S. National Museum; collected by Dr. Sergius Mamay in May, 1969, at an exposure of the Madera Formaation in the Manzano Mountains, southeast of Albuquerque, New Mexico.

'The type specimen consists of a nearly complete insect, with the two right wings outstretched and the two left wings superimposed (sec Figure I). The head is completely missing but there are remnants of the prothorax and of the anterior legs; the main part of the abdomen is not present but the last several segments and the cerci can be seen very clearly.

This insect has many interesting features. With a wing expanse of about $32 \mathrm{~mm}$, it is among the smallest Palaeodictyoptera known. The species of Lycocercus were much larger, with wing expansions of from $140 \mathrm{~mm}$ to $150 \mathrm{~mm}$. The transverse banding on the wings, although strikingly preserved, is not uncommon in the Palaeodictyoptera, including the species of Lycocercus. The form of the cerci is especially interesting, the marked bowing being very distinct. This curvature of the cerci has been seen or at least suspected in several species of Palaeodictyoptera, from both Upper Carboniferous and Permian deposits. The type specimen of Lycocercus goldenbergi, although preserved in a side view, shows a similar curvature (see Kukalová, I969, Fig. 32). Two faintly preserved but dis-

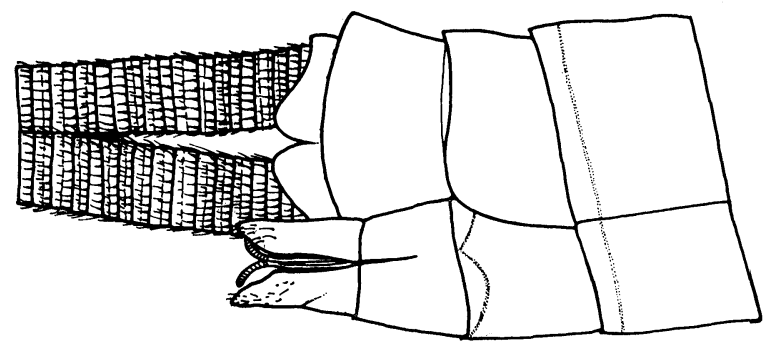

Fig. 3. Dunbaria fasciipennis Tillyard (Lower Permian of Kansas; from original drawing by Dr. Kukalová, based on type specimen in Peabody Museum, Yale University). 
tinct processes extend beyond the end of the abdomen between the cerci ; their exact nature is not clear but they are probably homologous to similar structures observed in the spilapterid Dunbaria fasciipennis, from the Lower Permian of Kansas (Figure 3) ${ }^{3}$. Presumably these processes are ventral to the cerci.

\section{Family Eugereonidae}

The type genus of this family, Eugereon, is known only from the Lower Permian of Germany but Dictyoptilus and Peromaptera are known from the Upper Carboniferous of Commentry in France, and Valdeania is known from the Upper Carboniferous of Portugal (Kukalová, 1969). The fore wings in this family were long and narrow, with a dense pattern of cross veins, often forming a coarse network; the hind wings were at least considerably shorter and had a modification of the venation basally.

I have assigned the specimen from the Sandia Montains in New Mexico to this family, placing it in the following new genus.

\section{Genus Sandiella, new genus ${ }^{4}$}

Fore wing similar to that of Dictyoptilus but with a much coarser reticulation of the cross veins and without the rows of regular cross veins, mainly unbranched, between the radial sector and Rl, and between $\mathrm{Rl}$ and $\mathrm{Sc}$; the subcosta terminates well before the apex of the wing rather than almost at the apex as in Dictyoptilus. The hind wing is unknown.

Type species: Sandiella readi, n. sp.

\section{Sandiella readi, n. sp.}

Figure $4 \mathrm{~B}$

Fore wing: length, as preserved, $40 \mathrm{~mm}$; estimated complete length, $60 \mathrm{~mm}$; width, Io $\mathrm{mm}$. Rs with seven main branches (branching probably variable within the species); MP with four branches, as in sepultus; cross veins numerous, irregular, and forming a coarse reticulation over most of the wing. Venational details are shown in Figure ${ }_{4} \mathrm{~B}$. The species is named for Dr. C. B. Read, who, over a period of years, has sent me many fine Paleozoic insects.

Holotype No. I70364, U. S. National Museum, collected by Dr. C. B. Read in I94I in the Sandia Formation on an exposure on the north side of Santa Fe Creek in the eastern suburbs of the city of

\footnotetext{
${ }^{3} \mathrm{I}$ am indebted to Dr. Jarmila Kukalová for permission to use this unpublished figure of Dunbaria. (See also Kukalová, 1971).

${ }^{4}$ The name of the genus is derived from that of the Sandia Mountains in New Mexico and is considered feminine.
} 

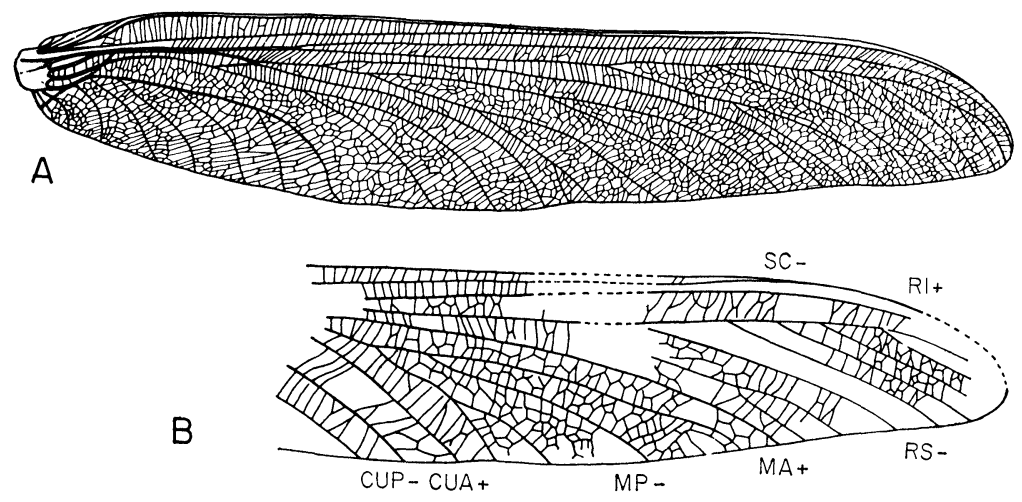

Fig. 4. A. Dictyoptilus sepultus (Meunier), drawing of fore wing (Upper Carboniferous of Commentry, France; from Kukalova, 1969). B. Sandiella readi, n.sp., drawing of fore wing (Sandia Formation, New Mexico).

Santa Fe, New Mexico (locality no. 894I, Geological Survey). The type specimen consists of the apical three-quarters of a fore wing, moderately well preserved; the details of venation and of the cross veins have been worked out by the application of alcohol and glycerine to the specimen.

The similarity of the preserved part of this wing to the fore wing of Dictyoptilus is very striking (see Figures $4 \mathrm{~A}$ and ${ }_{4} \mathrm{~B}$ ). It is becoming increasingly clear that the apparently local distribution of the families of Palaeozoic insects has been largely the result of the distribution of collecting patterns. The families were probably just as widely distributed as most families of insects at the present time.

\section{Order Caloneurodea}

\section{Family Permobiellidae Tillyard}

This family, which has previously been found only in the Lower Permian deposits of Kansas, is characterized by having the subcosta terminating at about mid-wing, by having three branches on the radial sector and by having $\mathrm{CuA}$ and $\mathrm{CuP}$ close together proximally but diverging distally. Only the genus Permobiella Tillyard, with its type species perspicua Tillyard, is known (Carpenter, 1943).

The fossil from New Mexico appears to belong to this family. It clearly has the relatively short subcosta and the three-branched radial sector. $\mathrm{CuA}$ and $\mathrm{CuP}$ are close together proximally but since $\mathrm{CuP}$ is not preserved distally, its terminal relationship to $\mathrm{CuA}$ is unknown. The general venational pattern of the specimen from New 
Mexico is very similar, so far as can be seen in the type specimen, to that of Permobiella. There is one other genus of the Caloneurodea which has the short subcosta, this being Anomalogramma from the Lower Permian of Kansas. However, Rs in this insect has only two very short branches and the anal veins are quite differently formed.

\section{Genus Pseudobiella, new genus}

This includes species similar to those of Permobiella but with the cross veins normal or relatively weak, instead of very strongly convex, as in Permobiella. Both fore and hind wings are marked by several strongly contrasting transverse stripes, unlike those of Permobiella, which are without markings of any kind. Since the basal portion of the wing of Permobiella is unknown, it might be noted here that four anal veins are distinctly preserved in the hind wing of Pseudobiella fasciata; three anal veins are preserved in the fore wing, which, however, lacks the more basal region.

Type species: Pseudobiella fasciata, n. sp.

\section{Pseudobiella fasciata, n. sp.}

Figures 5 and $6 \mathrm{~A}, 6 \mathrm{~B}$

Fore wing: length, as preserved, I I $\mathrm{mm}$ (estimated complete length, II.5 mm); width, $2.5 \mathrm{~mm}$. Hind wing: length, as preserved, Io $\mathrm{mm}$ (estimated complete length, I I $\mathrm{mm}$ ); width, 2.5 $\mathrm{mm}$.

Holotype: No. I70366, U. S. National Museum; collected by Dr. Sergius Mamay in May, 1969, at an exposure of the Madera Formation in the Manzano Mountains, southeast of Albuquerque, New Mexico.

As can be seen from the photograph (Figure 5), this specimen consists of all four wings and parts of the body (the head, antennae and thorax); the abdomen is completely missing. The venation is clear where it is preserved at all and the nature of its preservation is very unusual. The veins are distinct in those portions of the wings that were originally heavily pigmented but they are completely absent from the parts of the wings that were presumably hyaline or unpigmented. The symmetry of hyaline areas of all the wings shows that this is not just an apparent distribution of pigment but that it reflects the original color pattern of the wing. The left fore wing, as preserved in the fossil, extends to one side but the other three wings are aligned more or less in an overlapping position over the abdomen. Since these wings rest at slightly different angles, I was 


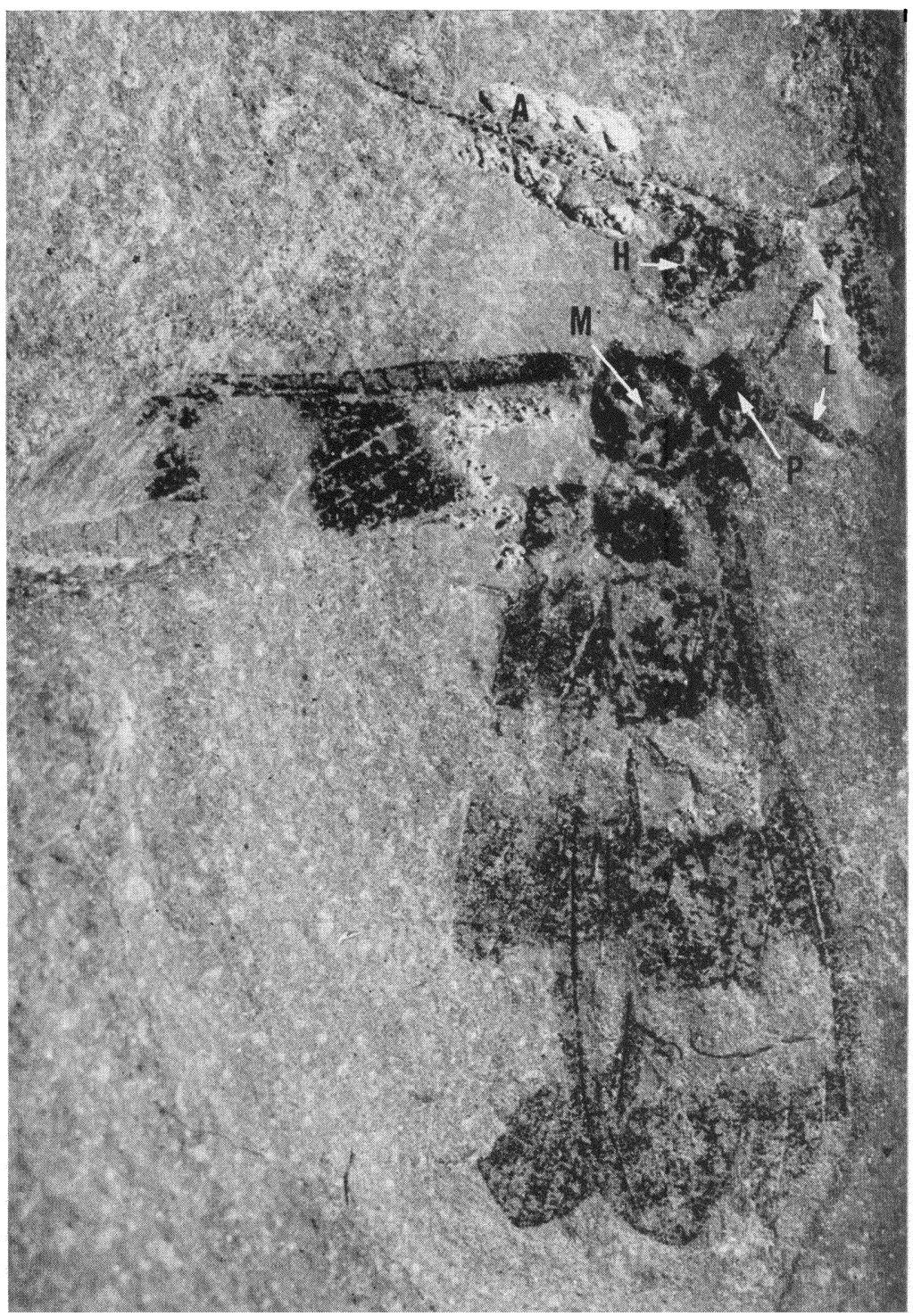

Fig. 5. Pseudobiella fasciata, n.sp., photograph of holotype (Madera Formation, New Mexico). A, antenna; $\mathrm{H}$, head; $\mathrm{P}$, prothorax; M, mesothorax; L, prothoracic legs. 
able, by using photographic enlargements and colored ink, to trace out the veins belonging to each of the three wings. This has resulted in a composite picture of a fore wing (based on two wings, one of which is isolated from the others) and a composite picture of the two hind wings. Of course, technique cannot restore the portions of the wing which are missing in the unpigmented areas. However, it is possible, because of the simplicity of the venational pattern, to restore with confidence the general venational pattern in the missing areas.

The fore wing margin is very slightly concave, the wing being broadest beyond the termination of the subcosta; in contrast, the anterior margins of wings of most Calaneurodea are straight or

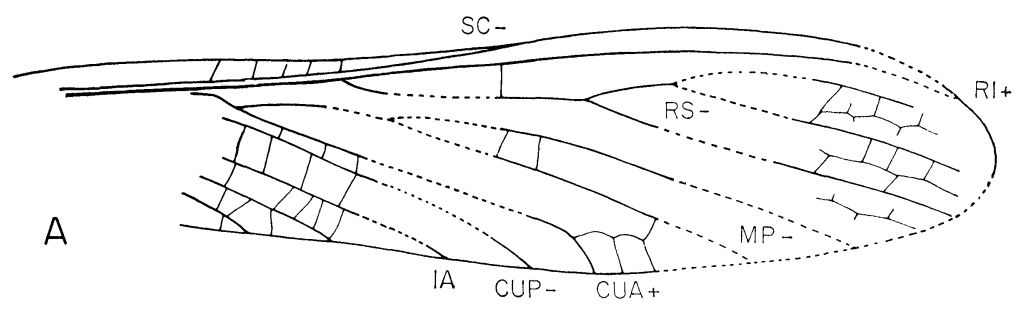

B
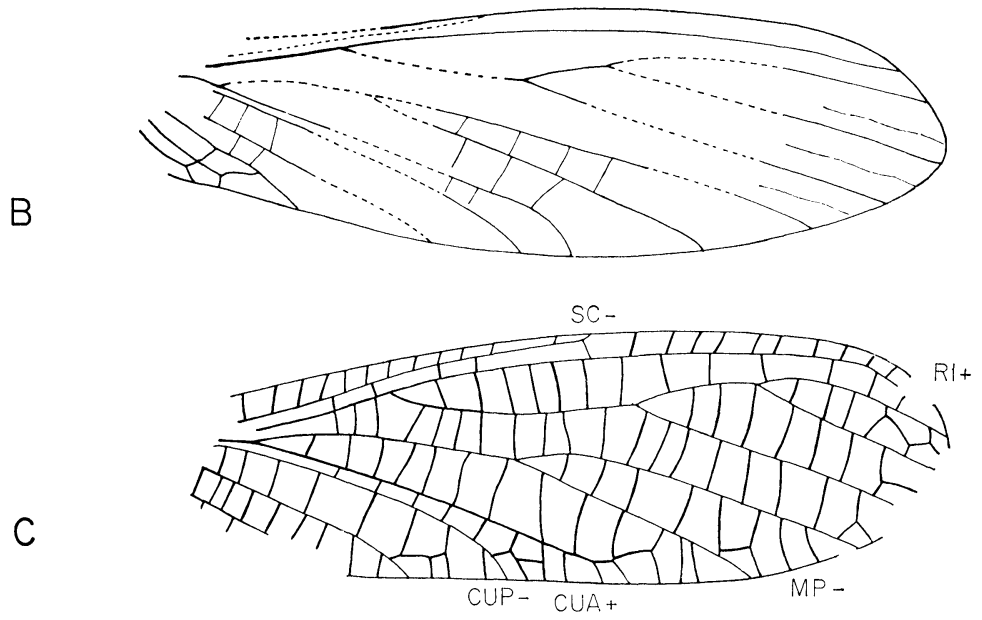

Fig. 6 (A) and (B) Permobiella fasciata, n.sp, drawing of fore (A) and hind $(B)$ wings.

(C) Permobiella perspicua Tillyard (Lower Permian of Kansas; original drawing based on type specimen, Peabody Museum, Yale University and other specimens in the Museum of Comparative Zoology). 
nearly so, although the wing of Pseudogramma (Permian, USSR) is slightly concave towards the base. The radial sector of $P$. readi arises well before the end of Sc, as in Permobiella; only its basal stem is perserved in that region but it is distinct again at about the level of the termination of the subcosta. The forking of Rs is very clear, forming three terminal branches, as in Permobiella. Between the branches of $\mathrm{Rs}$ and between $\mathrm{R}_{4}+5$ and $M A$ there is an alignment of cross veins, forming a weak, irregular vein which extends only a short distance back from the wing margin. Similar irregular veins are found in some Caloneurodea previously described, such as Permobiella, Caloneurella and Apsidoneura. $\mathrm{M}$ and $\mathrm{CuA}$ are anastomosed towards the base of the wing, as in other Caloneurodea; the forking of $M$ is not preserved but the two branches are preserved beyond the middle of the wing. $\mathrm{CuA}$ has the characteristic form of that of other Caloneurodea; between it and $\mathrm{MP}_{3}+4$ there are a couple of large cells formed by cross veins, very similar to those in Permobiella. $\mathrm{CuP}$ is close to $\mathrm{CuA}$, and the anal veins are more remote from each other. The cross veins are preserved only in pigmented portions of the wing; they are almost as numerous as those in Permobiella.

The hind wing, although about the same size as the fore wing, seems to have a somewhat different shape; the anterior margin is slightly arched. The venational pattern is basically like that of the fore wing, including the presence of the irregular secondary veins between the branches of the radial sector. An additional anal vein is visible in one of the hind wings.

The venational pattern of the wings, with restoration of some of the missing portions, is shown in Figures 3 and 4 .

Several body structures are preserved in the fossil. The abdomen, however, is completely absent in the half of the specimen which was collected; it probably was included in the counterpart. The mesothorax (Figure 5, M) and metathorax are clearly preserved, the mesothorax being somewhat the larger ( $1.5 \mathrm{~mm}$ length and width as compared with $\mathrm{I} .2 \mathrm{~mm}$ for the metathorax). These are almost circular, as they are preserved in the specimen. The prothorax $(\mathrm{P})$ has been broken away from the mesothorax and rests to the right side of the mesothorax (as preserved); attached to the prothorax are portions of two front legs $(\mathrm{L})$. The prothorax is I $\mathrm{mm}$ wide and $.7 \mathrm{~mm}$ long. The head $(\mathrm{H})$ is in the normal position with respect to the rest of the insect; it is I $\mathrm{mm}$ long and I.3 mm wide. Two slight bulges on each side may represent the 
eyes. One antenna $(A)$ is preserved for a length of $6.5 \mathrm{~mm}$ but quite clearly this is not the complete antenna, since it ends abruptly in the matrix. The other antenna is preserved only for a short distance from the head. It is probable that the antennae were at least as long as the fore wings.

The few body parts preserved in this specimen are consistent with those known in the Caloneurodea.

\section{Order Blattaria}

Two specimens of roaches were collected by Dr. Mamay in the Madera formation. One of these consists of an isolated fore wing and the other of a nearly complete insect, lacking the two fore wings. Because of the difficulty of making taxonomic assignments of Paleozoic roaches, I am not describing these specimens formally.

The second specimen, however, is of interest because it shows

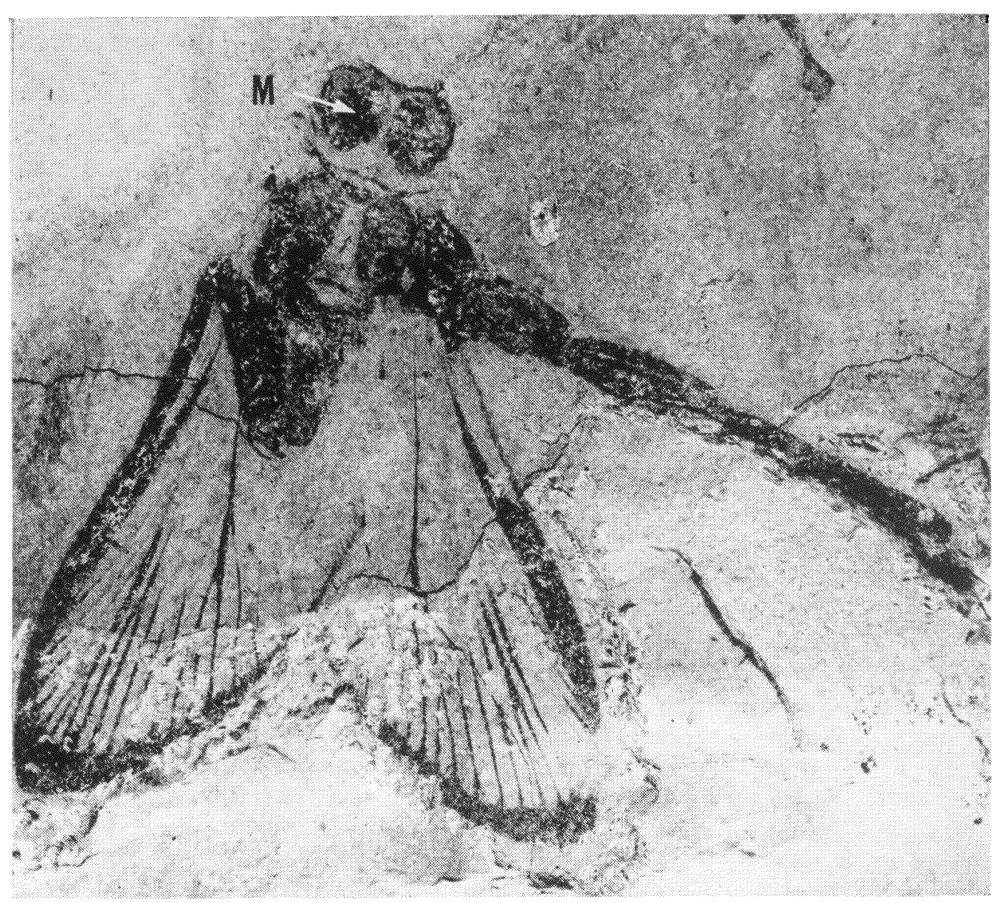

Fig. 7. Photograph of a roach (Blattaria) from Madera Formation, New Mexico. M, mesothorax. 
the hind wings, which are very little known in Paleozoic roaches. As shown in the photograph (Figure 7), the specimen shows part of the thorax, apparently a middle and hind leg, and the two hind wings, the length of the complete hind wing being $20 \mathrm{~mm}$. The thorax has obviously been crushed and distorted but the mesothorax (M) can readily be distinguished, the former showing scars of the dorsoventral muscles. However, one can distinguish a fairly large coxa, small trochanter and large femur and tibia; the segmentation of the tarsus is not preserved. The hind wing is of interest because of the preservation of most of the veins. The venational pattern is similiar to that of the hind wing which Tillyard described as belonging to the genus Pycnoblattina Sellards, from the Lower Permian of Kansas, although the Madera specimen shows a somewhat shorter subcosta. The posterior margin of the hind wing is clearly preserved to the level at which the anal fan presumably extended. This specimen indicates, as noted previously by Tillyard, that the anal area was very small in at least some of the Paleozoic roaches, in contrast to its development in most Recent Blattaria.

BATES, R. L. and others

\section{Literature Cited}

1947. Geology of the Gran Quivira quadrangle, New Mexico. New Mexico Bur. Mines and Min. Resources Bull., 26: 16-23.

Carpenter, F. M.

1943. The Lower Permian insects of Kansas. Part 9. Proc. Amer. Acad. Arts and Sci., $75(2):$ 55-84.

Keroher, G. C. and others

1966. Lexicon of geologic names of the United States for 1930-1960. Part 2: 2315-2316; Part 3: 3436-3437.

Kukalová, J.

1969. Revisional Study of the Order Palaeodictyoptera in the Upper Carboniferous Shales of Commentry, France. Part II. Psyche, 76: 459-486.

1971. The Structure of Dunbaria fasciipennis Tillyard (Palaeodictyoptera). Psyche, in press.

READ, C. B. and others

1944. Geologic map and stratigraphic sections of Permian and Pennsylvanian rocks of parts of San Miguel, Santa Fe, Sandoval, Bernalillo, Torrance and Valencia counties, north central New Mexico. U. S. Geol. Survey oil and gas Investigations, Preliminary Map, 21.

REAB, C. B. and G. H. Wood

1947. Distribution and correlation of Pennsylvanian rocks of late Paleozoic sedimentary basins of northern New Mexico. Journ. Geol., 55 : 220-236. 

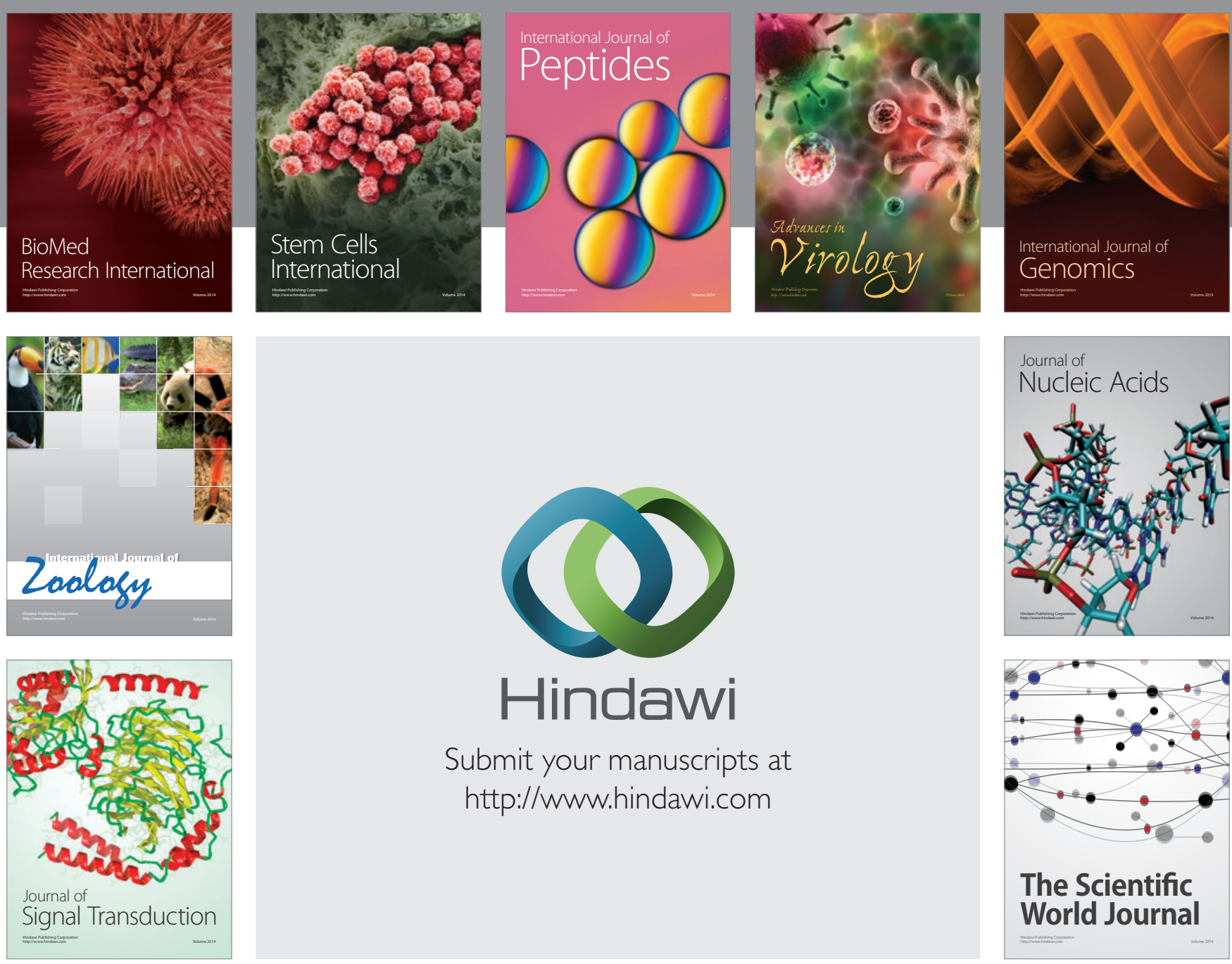

Submit your manuscripts at

http://www.hindawi.com
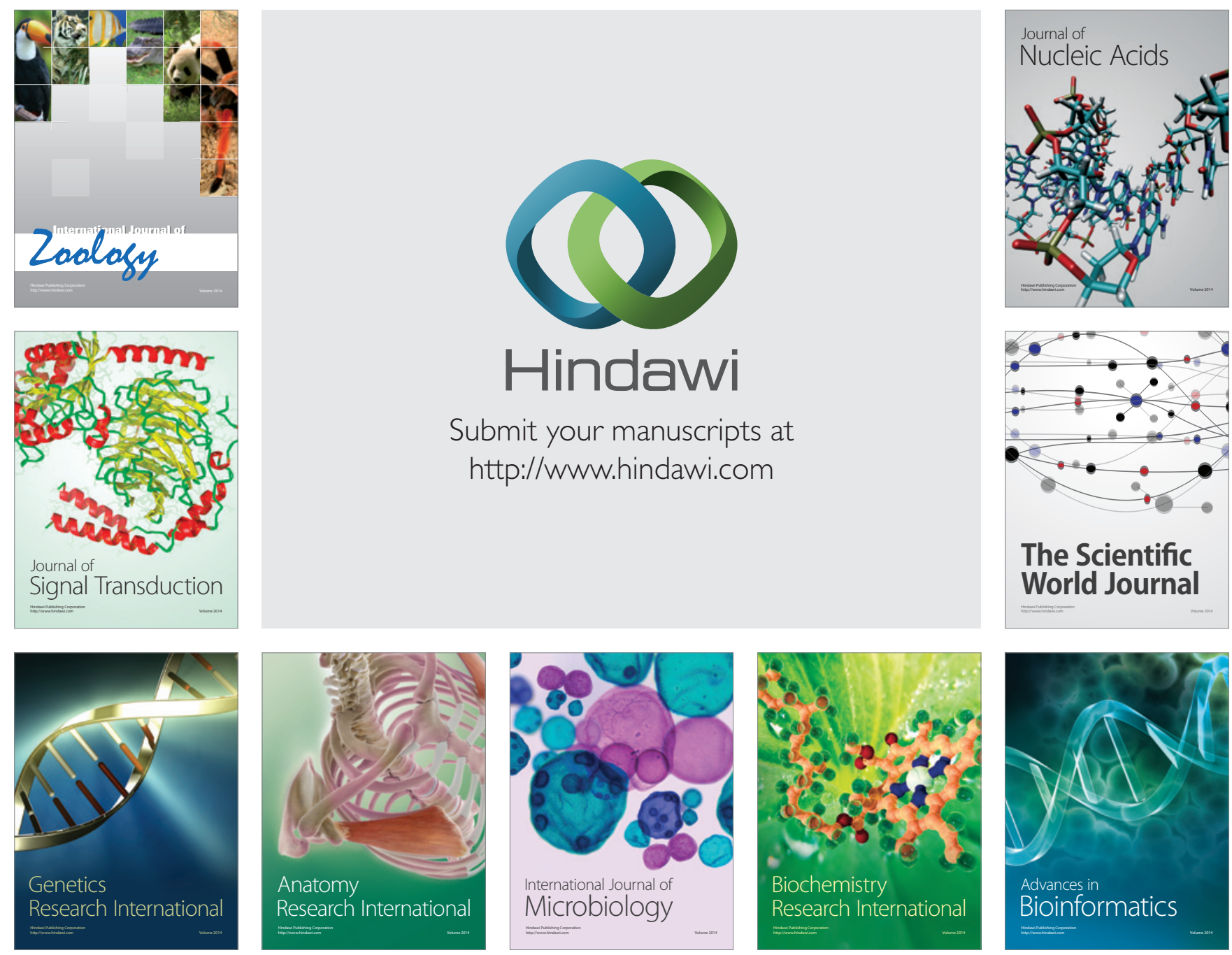

The Scientific World Journal
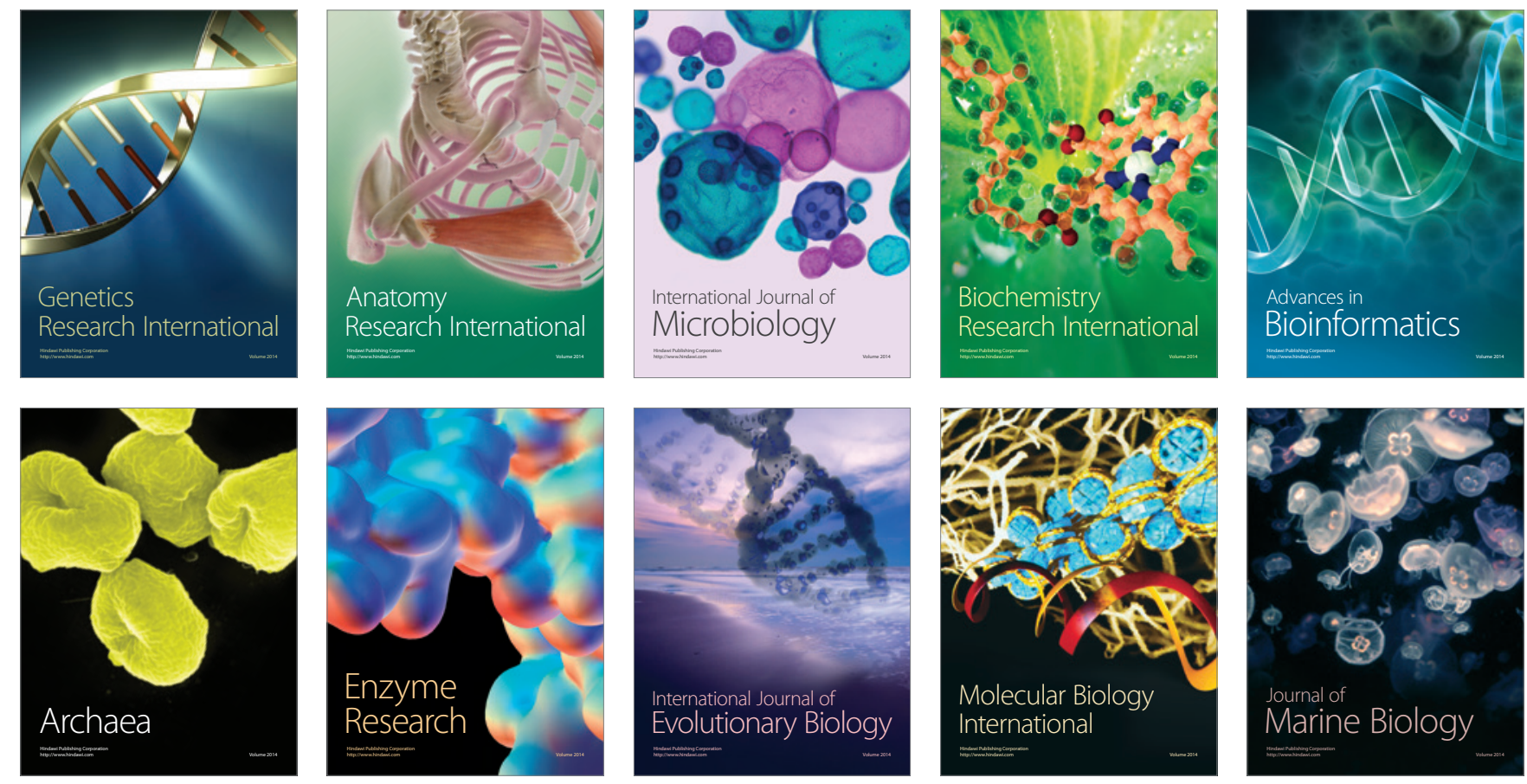